\title{
18世紀初頭江戸城工事に見る工事手伝と幕府工事組織 \\ TETSUDAI AND BAKUFU CREW ON THE RECONSTRUCTION OF THE EDO CASTLE IN THE EARLY DAYS OF THE 18TH CENTURY
}

藤尾 直 史*

Tadashi FUJIO

\begin{abstract}
This paper is on tetsudai and Bakufu crew on the reconstruction of the Edo castle in the early days of the 18th century. The sense of this paper is as follows;

1. This paper treats of the 18th century, which is rarely treated of in the former papers.

2. This paper treats of tetsudai, especially the relationship between tetsudai and Bakufu crew.

3. This paper treats of Bakufu crew, especially the relationship between Sakujikata, Kobushinkata and Fushinkata,

which I myself have treated of several times in my former papers.
\end{abstract}

Keywords: Tetsudai, Bakufu, Bugyo, Toryo, Edo castle, 18th century

手伝、幕府、奉行、棟梁、江戸城、18 世紀

\section{0 序}

本稿は 18 世紀初頭江戸城工事を素材に、工事手伝と幕府工事組織 を論じようというものである。周知のとおり江㳦に関する論稿は 決して少なくはない。だがここでの江城はあくまで素材であり、 主眼は工事手伝と幕府工事組織を論ずることにある。したがって本 稿と直接関わるものはおのずと限られてくる。

本稿の特徽の 1 点目は江戸中期 の注目である。江戸城に関する 従来の論稿はじつは扱っている時期に偏りが見られる゙。この点はあ まり認識されていないようだが、江戸城を論ずる上で無視できない 点である。江戸中期を扱う本稿は一定の意義を有すると言える。

本稿の特徴の 2 点目は手伝への注目である。この手伝への注目も じつは意外に限られている゙。本稿では特に江戸中期に注目した上で、 手伝と幕府組織を関連づけて論じようとしている。この点でも本稿 は一定の意義を有すると言える。

本稿の特徽の 3 点目は幕府組織への注目である。周知のとおり江 戸幕府には作事方・小普請方・普請方という3つの役所があった。 そして作事方は田辺・大河・西、小普請方は鈴木・内藤・中村 ${ }^{6} の$ 諸氏がそれぞれ詳しく論じてきた。普請方も批稿てでその一端を論じ た。ころが三者の相互関釈はなお検討の余地を残している。この 点は陉稿でも綝返し強調してきた点であり、本稿はこのような既発
表の批稿の成果を踏まえつつ、18 世紀初頭江戸城工事の工事手伝と 幕府工事組織を論じようというものである。

以下ここでは便宜上、(1)手伝、(2)奉行、(3)会所・棟梁の3つに分 けて論ずるが、いずれも工事手伝と幕府工事組織を関連つけて論ず る点では変わりがない。

\section{1 手伝}

1.1 壮様

【史料 1.1$)^{9}$

一、御城内外御多門御櫓仕槏帳、対馬守殿江致進達之、此通段々申付候、思召 も御座候心ジ，追而被仰聞侯槏二申上候

【史料 1.2】

一御手伝方七手之家来、小屋江呼、面々丁場御普請之仕様帳、壱冊宛相渡 之

【史料 1.1】は宝永元年（1704）正月 22 日のものである。城内・ 城外の多門・櫓の仕様帳を、若年奇一作事・普請奉行らが進達し、 仕様帳通り段々に申付け、思うことがあれば追って述べるよう申上 げたとする。

【史料 1.2】は正月 24 日のものである。手伝 7 手の家来を小屋人 呼び、面々の丁場の仕様長を 1 冊ずつ渡したとする。これ俚手伝が 奉行らから仕様帳を受取る立場にあったことを意味している。 
以上 2 点の『史料】では特に手伝が奉行らから仕様帳を受取る立 場にあった点が注目される。

\section{2 人足}

【史料 2.1】10

賞

一、古来より御手伝方本役声方石一日二百人宛出三侯䄯り、左候人“御扶持方 公儀より一日百人扶持宛被下候、半役二候得保壳万石一日二五拾人ツ、出候程 り御座侯、去儿天和三亥/年日光御宮・御堂御石垣築直:御手伝、丹羽若㹟守 本高拾万石・役高七万石、内藤左京亮本高七万石・役高五万石、津䃽越中守本 高四万石・役高三万石、真田伊豆守本傐拾万石・役高七万石、戸沢能登守本高 六万八千武百石・役高五万石之積り二被仰出候、以上

$$
\text { 二月 } \text { 日 }
$$

【史料 2.2】

立花飛墇守役人

諸日用賃金定觉

一川並壳人 三五分

一、上震 壱人 声五分

，中葴 壱人 武多八分

一、幅太 壱人 三斥人

一、平人 壱人 武多

一 千本乫壳人 壱名

一枝突 壱人 壱多五分

右御石坦御手伝被仰付候七家㕍人足、旧冬迄之分值銀如此二相極申侯、以上 正月十三日

《史料 2.3】

一、八手之御手伝元 申合、当春より人足石方顀銀定之書付、対馬守殿江上申 候事

【史料 2.1】は手伝の役に関するものである。昔から手伀の本役 は1 万石あたり1 日 100 人（半役は 50 人）、扶持は公儀から 1 日 100 人扶持だったとする。表 1-a に宝氷工事の数值をまとめた。一方天 和 3 年（1683）の日光御宮・御堂の石垣工事の本高と役高は表 1 のようだったとする。ここでは具体的な数值とともに江戸城の工事 の際に日光の工事の先例を引いている点を確認しておく。

【史料 2.2】は手伝の諸日用の穓金に関するものである。ここで は日用を川並・上感・中感・幅太・平人・千本突・枝突の 7 種類に 区分している。そして石垣の手伝を仰付けられた7家の雇人足の旧 冬までの供銀をこのように決めたと述べている。これは手伝相互の 日用穓銀の統一が図られたことを意味している。

【史料2.3】は3月 9 日のものである。8 手の手伀元み゙で当春から の人足石方賃銀を定めた書付を若年寄人上げたとする。ここでもや はり賃銀の統一が図られている。

以上 3 点の【史料】では、(1)手伝の石高に応じて人足高が決めら れた、(2)手伝相互の日用貨銀の統一が図られた点が注目される。

\section{3 建材}

[史料 3.1》11

此御手伝人足入用 金式万三千百四拾乎程

此御手伝人足入用 金壱万三千式百四拾三禹程

此御手伝人足入用 金五千四百四拾九雨武分程

此御手伝人足入用 金五千五百壳雨武分余

此御手伝人足入用 金六千武百八拾武両余

松平大滕大夫

立花飛騨守

戸沢上総介

榣葉能登守

加藤逻江守

右御手伝人足入用金皘り、建前・石垣坪詰壱坪当り大稘り、如此御座候、此外 内証之入用之義は員数難計奉存候、以上 六月六日

『史料 3.2》

一、御用石払底、請負之石趈り合不申節は、御手伝方石請取候事滞侯故、其 内痽之人足手を明ケ申二付、御手伝方失追二罷成侯、結句其内自分二而調筑 七候方勝手能候由、依之御手伝方之内、左槏二も致度之申方も有之由二候間、

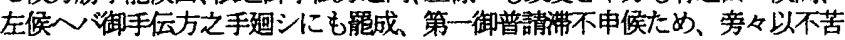
思矿候心、内証二て取は加以、右之通仕度と申方八、石滞候時分八御手 伝方二て調用させ、追而御勘定之節、右之わけ立、代金此方より御払二仕候

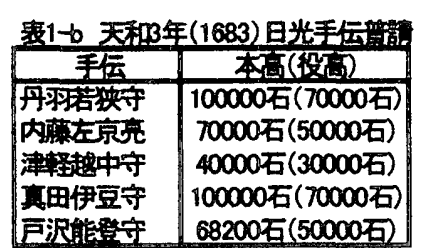

\begin{tabular}{|c|c|c|}
\hline 手倍 & 石高 & 人足要1日本高(半役)-100日本要 \\
\hline 平大肪大夫 & 3600007 & 3600 人 $(1800 人)-360000$ 人 \\
\hline 松平右保阴督 & 3200006 & $3200 人(1600 \lambda)-320000 \lambda$ \\
\hline 上杉民部大輔 & 1500005 & 1500 人(750人)-150000人 \\
\hline 立花飛漳守 & 109640 石 & 1090 人(545人)-109000人 \\
\hline 丹羽左京大夫 & 100700 石 & 1000 人 $(500$ 人) -100000 人 \\
\hline F沢上総介 & 68000 余石 & 680 人(340人)-68000人 \\
\hline 加盍学江守 & 600006 & 600 人(300人) -60000 人 \\
\hline 權㴰䇺守 & 50000 余厉 & $500 人(250 \lambda)-50000$ 人 \\
\hline
\end{tabular}

八ド可然哉と存寄候段、対馬守殿江御内意申上候処、一段可然事二候、対馬 守殿など八御存不被成候分二て、何丸も心得を以、右之通致させ可然由被仰 閏候、其段修理江申開候事

[史料 3. 3]

一、石・材木渡シ方之暑二付、御沙汰有之趣、御才不奉行手前承届候処、彼

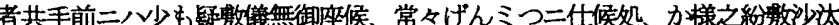
御座候而は致迷感候段申事候、しかれども肝聮之者又は請負之者など手前二 て紛敏義も有之候哉、此段無覚束と申候趣、彼是対馬守殿江委細申上候処、 御聞届候由御挨拶二候、且又石・材木請取候節、三日程前、会所江御手伝方 より申届候様二申渡固侯、此以後は右之届一承候と可申上候間、其節御徒目 付彼之場 被遗候梯二可被成哉之旨申上候 心 、尤思召候、先二三度も御徒 目付被望、様子御聞合可被成候間、右之通可相心得旨、被仰開候事

『史料 3.1》は6月 6 日のものである。手伝ごとの人足の入用樻 り、建前。石垣坪詰 1 坪あたりの大瞉りを書上げている。注目すべ きは「内証之入用」に言及する点である。

『史料 3.2】は6月 3 日のものである。御用の石が底をつき、請 負の石が出回らないと、手伝の石の受取りが滞り、人足の手があき、 手伝の「失追」となる。それなら自分で調えて築く方が勝手もいい し、実際そうしたいとするものもいるとする。そうすれば手伝の手 廻になり、工事も滞らないので、内証で取計らい、そうしたいもの は、石が滞ったら手伝の方て調えさせ、追って勘定の際に代金を払 うとしてはどうかと、若年㟢へ奉行らが「内意」を申上げたところ、

「心得」でそうせよとのことだった。あくまで心得とする点が興味 深い。

『史料 3.3】も同じく 6 月 3 日のものである。ここでは石・材木 の渡し方に関する沙汰が問題となっている。材木奉行の手前では 常々厳密にやっており、紛らわしい沙汰は迷惑とする。とはいえ肝 煎・請負人の手前では紛らわしいこともあるかも知れず、この点は 覚束ないとする。若年寄一委細を申上け聞届けられ、以後石・材木 を受取る際は、3 日ほど前に手伝から会所一届けるよう申渡された。 その際に徒目付を遗わしてはとの申上げももっともとされた。

以上 3 点の【史料』を見た。建材は官給が原則だったが、手伝の 裁量を容認する意向もあった。その背景には建材供給の不安定さも あった。もっともれはあくまで心得の範囲にとどまるものだった。

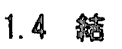

ここでは仕様・人足・建材の観点から、手伝の立場を論じてきた。 18 世紀初頭のこの工事では、手伝は(1)仕梯帳を受取り、(2)人足を出 し、（3建材を受取る立場にあった。もっとも建材供給の不安定さも あってか、手伝の裁量を認める意向もあったが、あくまで心得の範 囲にとどまるものだった。 


\section{2. 搴行}

\section{1 手伝・小兽锖}

【史料 4.1 1 $^{12}$

一、党

一、三之丸

一、紅萧山下

一、半藏御門より外桜田御門、馬場先御門察迄

一、山下御門より幸橋・虎之御門、溜池落口迄

此所御手伝割無之侯、榣葉能登守丁場少侯間、能登守江御加可被遊候哉と奉 存候

右之通御極可被遊㳦、奉窥候

一、清水御門

加藤遠江守

右は申渡相济

一、半蔵御門際上り田安御門、竹橋御門・清水御門際迄 御手伝無之場所 此所江御蔵御加可被遊哉、奉何侯

$$
\text { 十二月十七日 }
$$

右之通筧書、今日四人申合、於御成但馬守段江差出健処、大譜大夫丁場并勝 之助江大膡大夫丁場之内腾手次第被割渡候槏二可申渡旨、且亦丹波五郎三郎 江紅葉山下御門御手伝被仰付旨可申渡段、但馬守殿被仰聞侯二付、大腈大夫・ 五郎三郎家来小屋江呼寄、四人立合申渡之候、以上

【史料 4. 2】 覚

一、蓮池御門

渡り櫓取壊、石垣取除、仮木戸門申付候

一、日比谷御門

渡り檞取除、石垣繥、木戸門・仮翻所申付候

一、田安御門

渡り櫓取除、下御門其侭差置、仮屋根仕、石垣崩候所、危ク無之搛二取除 差置申候

一、大手・内桜田・外桜田・馬場先・和田倉 - 虎之御門 - 幸橋・山下御門

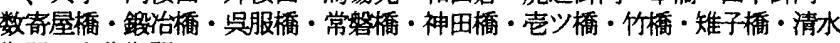
御門・半藏御門

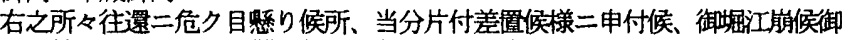
石垣等は、当年八片付難成候故、其通二差置申候

一、外郭公未御手伝不被仰付候故、少々危所も相見江候得共、片付不申候、 小普請方江成共片付候様二可被仰付候 十二月世四日

【史料 4.1】は元禄 16 年 (1703) 12 月 17 日のものである。場所 ごとの手伝を伺っている。注目すべきは、三之丸は小普請方とある 点である。形式上手伝と小普請方の分担を伺っていることとなるか らである。しかも老中に対して作事・普請奉行ら 4 人から伺ってい る。つまり手伝と小普請の分担を作事・普請奉行らが伺っているこ ととなるのである。

【史料 4.2】は同年 12 月 24 日のものである。多くの門を当分片 付け差置くとしている。現在も残る田安門は渡櫓を取除き「下御門」 はそのまま差置くとするのは、清水門・外桜田門の扱いとも合わせ て注目される ${ }^{13}$ 。な招外遊はこのときまだ手伝を仰付けていなかっ たため、少々危なくても片付けず、小普請方にでも片付けるよう仰 付けるべきとしている。ここでもやはり手伝と小普請の分担を問題 としているのである。

以上 2 点の【史料】はいずれも手伝・小普請の分業体制を示した ものである。手伝・小普請の分業体制は、作事・小普請の分業体制 の反映ともいえようが、18 世紀衫頭のこの工事では実際上は手伝・ 小普請の分業体制が問題となっている点が注目される。

\section{2 作事・童鲭弿行 \\ 【史料 $5.11^{14}$}

$$
\text { 党 }
$$

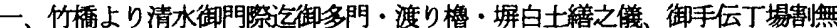
御座所二候間、小普請方より綘侯梯二奉存候、以上 十二月廿日
【史料5.2】

賞

一、富士見御櫓より西拮橋迄之内、御概・御多門・塀白土、小普請方より申 付候様二被仰渡可然奉存候

一、先頃大和守段被仰渡候紅葉山・西之丸境塀之儀見分仕㑨処、奥方御構之 内江右御手伝人足難入所二下候間、小普請方より總仕候様二被仰渡候二と奉 存候

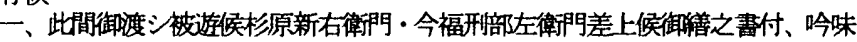
仕候処、紅葉山御構之内、其上御宝藏之内二て手伝方人足難入奉存候間、是又 小普請方より申付候様二被仰渡、御尤奉存侯、以上 十二月廿四日

水野権十郎 甲婓庄喜右衛門 大島肥前守 松平伝兵衛

【史料5.1】は元禄 16 年 12 月 20 日のものである。竹橋から清水 門までの多門・渡櫓・堀城士は、手伝の丁場の割当てがないところ は、小普請方が緟うとする。作事奉行・普請奉行らから出ている。

【史料 5.2】は同じく 12 月 24 日のものである。富士見橹から西 拮橋の櫓・多門・塀白土は、小普請方から申付けるように仰渡す心゙ きとする。また紅葉山と西丸との境の塀を見分したところ、奥方の 構えの中に手伝人足は入れにくいので、小普請方から絴うよう仰渡 すとする。さらに杉原・今福占から差上げた繕いの書付を吟味した ところ、紅葉山の構え、宝蔵の中のため、やはり手伝人足を入れに くいので、これも小普請方から申付けるよう仰渡すのがもっともと する。'このように手伝・小普請の場所分けに、作事・普請奉行らが 関わっているのである。この点は手伝と奉行の関係とともに、小普 請奉行之作事・普請奉行の関保を考える上でも重要な点と言える。

以上 2 点の【史料】も手伝・小普䄇の分業体制を示している。注 目すべきは両者が作事・普請奉行らから出されている点だろう。

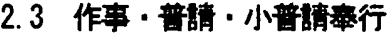

[史料 6. 1] 16

此度御普請大工之儀、御作事方支配之大模梁、小普請方支配之大棟梁打迈相 勤、工割之義甲乙無之様二可被申付候、右之通、稻垣対馬守殿江相賽、如此 二候間、可被得其意候、以上

$$
\text { 十二月五日 }
$$

曲淵伊左衛門 布施長門守 水野権十郎

甲斐庄喜右衛門 大島伊勢守 鈴木修理殿

松平伝兵衛

\section{【史料 6.2】 17}

一、御玄関前溜り之内、大狐・小狐之銘御座候大石、拾間御多門入隅之方江 三分・二分・三分一面习出シ候べ゙丈夫二御坐候間、右入隅江一つ之石引込 申度奉存候二付、色々相談仕侯処二、二重御櫓台石垣と拾間多門石垣之間、 八尺九寸御座候、此所掘候一“゙二重御櫓台石垣危罷成候、御櫓江もさわり申 候二付、大石引込候儀難成奉存候

一、右式本之石、同所有来候石垣根石 7 取、武尺余も掘込、根石二御用人可 被遊哉

一、右之通、大工棟梁・石屋棟梁久二郎畫付出三候二付、私共儀も見分仕候 所、棟梁共申侯通二奉存候間、奉窥候、以上 申六月

松平伝兵衛 大島肥前守 甲婓庄喜右衛門 水野権十郎 布施長門守 曲淵伊左衛門

【史料6.3】 鈴木修理

神田橋渡り御櫓下西南之方御門台・石垣見分仕候処二、丈夫二八相見江申候、 然共少々石口目違又は石痛候所抔御座候間、能分八残三㯰、覀教所は弥策直 二仕可然奉存候、以上 七月十三日
松平伝兵衛 大島肥前守

甲斐庄喜右衛門 水野権十郎 布施長門守 曲淵君左衛門 


\section{右は七月十三日二对馬守殿江御上ゲ候控}

【史料6.1】は元禄 16 年 (1703) 12 月のものである。若年寄の稲 垣対馬守人窥った後に、小普請奉行の曲覑・布施、普請奉行の水野。 甲斐庄、作事奉行の大島・松平から鈴木几出されている。今回の工 事は作事方支配の「大棟梁「と小普請方支配の「大棟梁」が「打込」 で勤める、工割に「甲乙」がないように申付けるとする。この点は 既に論じた ${ }^{18}$ 。

【史料6.2】は宝永元年 (1704)6月のものである。玄関前の大狐。 小狐の銘を有する大石の扱いが問題となっている。注目すべきは、 (1)大工棟梁・石屋棟梁の書付に基づき見分を行っている点、(2)作事 奉行・普請奉行・小普請奉行・鈴木らが連署している点である。

【史料 6.3】は 7 月のものである。神田橋の渡櫓の下、西南の方 の門台・石垣を見分したところ、丈夫には見えるが、目違や痛みも あるので、良い分は残し、悪い所は築直すべき、と説いている。

以上 3 点の【史料】では特に作事・普請。小普請奉行の三者が連 署している点が注目される。

\section{4 結}

作事・小普請の分業体制は、幕府組織を論ずる基本論点とされて きた。ここが 18 世紀初頭のこの工事では実質的には手伝・小普請 の分業体制が問題となっている。しかも両者の分業体制に関わる文 書を、作事・普請奉行らが連署・上奏していることもわかる。なお 作事・普請・小普請奉行の三者が連署するものもあった。

\section{3 会所・菻梁}

\section{1 会所}

【史料 7.1】19

所々二而おろし候瓦、丸・平其外品々之瓦、積分被差置、おろし仕迴候場 所より品々此方一御達可有之候、瓦見分之者被差遣候間、左様二御心得可有 之候、以上

$$
\text { 正月廿日 }
$$

七手御手伝方元 采中

会所

追面順々御廻し、会所一品々御返し可有之候、以上

【史料 7.2】

$$
\text { 覚 }
$$

一、冠木御門筋金物放シ侯義八、見分 有之事

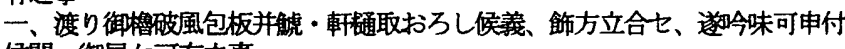
候間、御届ヶ可有之事

一、䂛鈎り金物并瓦留入金物、其外有来候古金物之義八、鋂治方立合七数改、 遂今味可申付候間、御届ケ可有之事
正月十六日
香川太郎兵衛殿
鲇川作右衛門殿
安東弥三右衛門殿
岡金左衛門殿
舟生源右衛門殿
南部与一兵衛殿
小泉七左衛門殿
河田助右衛門殿
長尾半藏殿
上田伊織殿
黒田伝太夫殿
中西権兵衛殿
井上左七郎殿
瀬川小兵衛殿

壱梧会所

【史料 7.1】は宝永元年（1704）正月 20 日のものである。7手の 手伝らの元バ恤中へ、会所から出されている。所々で下ろした瓦は、 丸瓦・平瓦・その他の瓦に分け、場所加会所入達するよう求めて いる。そうすれば見分のものを遣わすからそのように心得よとして いる。手伝と幕府組織の関係を示寸ものと言える。

【史料7.2】 は正月 16 日のものである。やはり 7 手の手伝の元片 らへ会所から出されている。冠木門の筋金物を放したら、見分を遗 わし吟味を行うよう申付けるから届けること、渡櫓の破風包板・鯱。 軒戟を下ろしたら飾方のものを立合わせ吟味するよう申付けるから 届けること、硧鉝金物・瓦留金物などの古金物は鎪治方を立合わせ

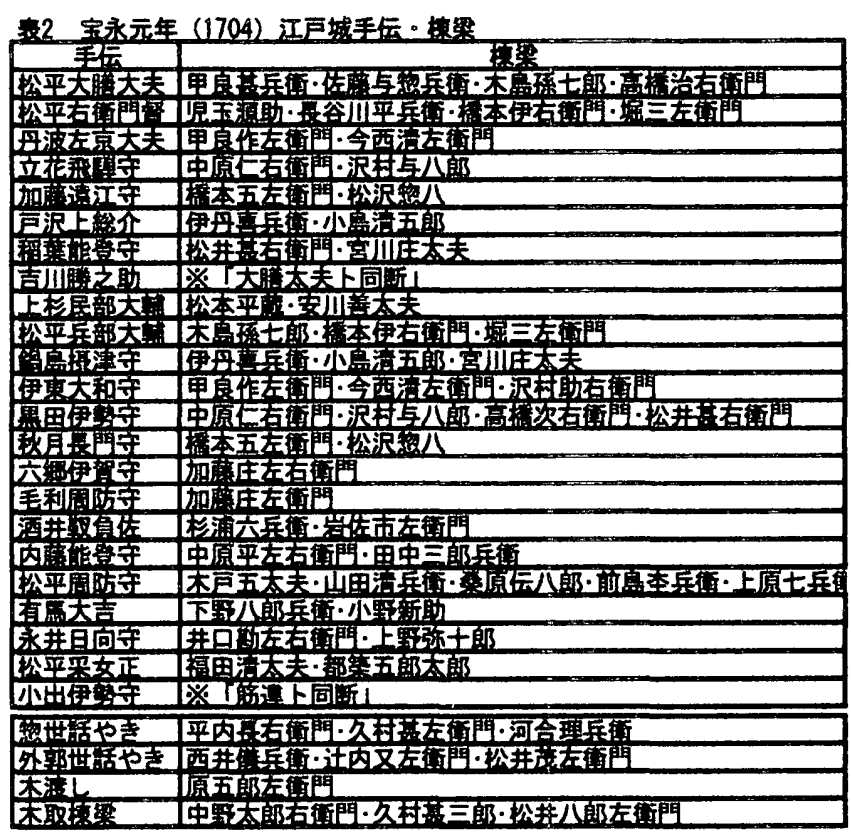

数量を改め吟味するよう申付けるから届けることとしている。

以上 2 点の【史料】は瓦・金物など旧来の建材の扱いに関するも のだが、いずれも手伝らの元抆対して会所から出されており、こ の点は建材が原則官給だったこととも合わせて注目される。

\section{2 棟梁}

【史料 8.1 10

前書

一、此度御手伝方上り音物等受納仕候品々、不皧置可申上旨奉畏候、先頃被仰

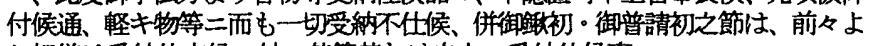
り祝儀は受种仕来候二付、其節其わけ中上、受納仕候事

一、向後若御手伝方より音物等も御座候八、受納不仕、早速可申上候、尤仲 間中二而も受納仕侯者御坐候八バ、承出シ次第、早速可申上候事 - 先条被仰付候通、弥以慜相守可申事 骮文

宝求元申年五月

杉本源兵衛 鈴木貞右衛門 坂本七左衛門 松坂源太郎

松平伝兵衛毁

大島肥前守殿

甲斐庄喜右衛門殿

水野権十郎

依田藤右衛門

清水弥左衛門

增田清右衙門

史料 8.2

口上之覚

陉者共仲間何も御手伝方上り御音信製御座侯、御自分之御頼御用被仰付侯御方 より八、御頼被成候御礼金銀被下候以上

五月晦日

松井䟢七郎 射阿弥喜七郎 同 才兵衛 高井弥慜右衛門

同 五郎兵衛 鈴木又三郎 安間源太夫

史料 8.3》

觉

一、町棟梁之義は、従公儀御扶持方被下侯者二而も無御唑候、御暀之者二付徒 公儀一切被下物も無御坐侯、㥎而御手伝方埸所御普請之様子二より、武人・三 人もわ力柎付申侯、就夫御用之外御手伝方御自分之場所二而、絵図・差図・榴 り物。釷払等、御手伝役人白人之不罷成義八、前々より内証二而御頼、用事相 弁申候二付、入用等も緜り候二付、相対二而私金等被給侯由承申候、此義は拙

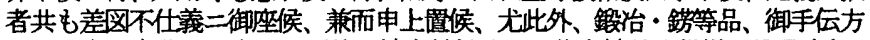
二而紛失、自分より内証二而仕足被申付候分八、代金被差出候搛二及承申候、 ケ様之義御聞まがいも可有御坐義と申上置侯、以上 五月廿九日

鈴木修理 【史料 8.4 】

一、御手伝方より音物等受用不仕候趣之義、且又前以申付候通、弥可相守段、 御被官不残小屋二而神文申付候、棟梁仙修理宅二而誓旨申侯事 
【史料 8. 5】

一、製御手伝方より末々之者迄 音物何二而も不被相送候㨾二、家来共人申渡 置度由、但馬守殿・対馬守殿江御内意承候処、不苦候間、何も以意得申聞候槏 二と被们候故、則小屋二厂面々家来一申渡之候事

一、此間被饮聞侯義二付、末々之者迄急度申付、神文致させ、御初・御普神 初前々より受納仕来侯音物之外、受不申候段、且又向後怪キ物二ても受納仕間 舖旨、堅ク申渡候由、其外何九も存寄之義、但馬守殿・対馬守殿江委細申上候 事

一、町棟梁之儀二付、鈴木修理差出三候書付、対馬守殿江致進達候事 【史料 8.6 】

一、御手伝方御算用仕上ゲ候節公、町棟梁頼申事二候、是又自分㕍候間、外二 楅銀もらい申二而可有御坐候、此旨前々申上固侯得共、まぎらわ散御聞江も候 二付、弥為御门得、重而御物語仕候由、対馬守殿一申上侯得ば、御聞届ケ御尤 之由被仰閶候事

【史料8.1】は宝永元年（1704）5月のものである。手伝から音物 など受取った品々は隠さず申上げる、軽いものでも一切受取らない、 鉔初・普請初など以前から受取ってきた祝儀はわけを述へてて受取る、 今後手伝から音物等があったら受取らず早速申上げる、仲間で受取 ったものがいたら早速申上げるなどとする。

【史料 8.2】は5 月晦日のものである。壁方・鍛治方・錺方など諸 方の棟梁らが連署している。手伝から音信はない、御用を頼まれた ら御礼金銀を下されるなどとする。

【史料 8.3】は 5 月 29 日のものである。作事方町棟梁は、公儀か ら扶持を下されるものではなかった、㕍いもので公儀からの下され ものは一切なかったとする。まずはこの点が重要である。今回の工 事では手伝の場所の様子により、町棟梁が 2-3 人ずつ分かれていい ていた。【表 2】に具体像をまとめた。注目すべきは御用のほか手伝 の場所で絵図・差図・積物・釗払など手伝役人、素人が出来ないこ とは、以前から内証て頼んだとする点、用事をわきまえ入用もかか るため、相対で私金を給するとの話もあるとする点である。もつと もこれは鈴木の指示ではないとあらかじめ奉行らに申上げている。 また鉔冶・錺などの品を手伝が紛失し、そのため内証で足すよう申 付けた分は、代金を出しているとの話もあったようで、誤りもあろ うとはしつつも奉行らへ申上げている。

【史料 8.4】は 5 月晦日のものである。手伝から音物等を受取らな い以前申付けた通りに守る、被官は残らず小屋で神文、棟梁は修 理宅て誓呞とする。

【史料 8.5】 は6 月朔日のものである。手伝から末々のものまで、 音物を贈らぬ上う家来一申渡したいと老中・若年寄一奉行らから内 意を承って小屋で面々の家来へ申渡した。また末々のものまで急度 申付け神文をさせ鐉初・普請初など以前からの音物以外は軽いもの でも受取らぬよう堅く申渡したと申上げている。

【史料8.6】は10月 10 日のものである。手伝が算用を仕上げる際 に町棟梁一頼む。これは自分が㕍っているが、ほがも賃銀を貫っ ているようである。この点は以前も申上げたが紛らわしい話もあっ たため心得のためとして若年寄へ再度申上げもっともとされた。

以上 6 点の【史料】を見た。それぞれ手伝と被官・諸方棟梁・大 工棟梁 (町棟梁) との関係を示寸ものだが、最も注目されるのはや はり手伝の場所に数人ずつ棟梁 (町棟梁) らが関わり、業務の一端 を担ったとする点である。

\section{3 結}

ここでは手伝に対する会所・棟梁の立場の一端を論じた。手伝の 場所で出る使用済みの建材については、会所から見分を遗わすこと となっていた。この点は建材が原則官給だったことと合わせて注目 される。また手伝の場所に数人ずつの棟梁 (町棟梁)が付いていた。 この点恃に手伝と幕府組織の分業の実態を示すものとして注目さ れる。

\section{4 結}

本稿は 18 世紀初頍江戸城工事を素材に手伝と幕㿟組織を論じた ものである。まず手伝の立場を論じた。手伀は仕様を受取り、人足 を出す立場にあった。建材は原則官給だったが、供給の不安定さか ら手伝の裁量を容認する意向むあった。次に手伝と奉行の関係を論 じた。手伝・小普請の分業体制を作事・普請奉行が伺う立場にあっ た。この点は作事・普請・小普請の三者の関保を論ずる上で重要で ある。最後に手伝と会所・棟梁の関係を論じた。手伝の場所で出る 使用済みの貄材については会所から見分を遣わすこととなっていた。 この点は建材が原則官給だったことと合わせて注目される。また手 伝の場所に数人ずつの棟梁 (町棟梁) が付いていた。この点は特に 手伝と幕府組織の分業の実態を示すものとして注目される。

\section{注}

1 『東京市史稿』皇城篇（1911-）、村井益夫『江戸城》(中公新書、1964)、 文化財保護委員会編集発行『重要文化財旧江戸城田安門、同清水門修理工事 報告書丹(1967)

${ }^{2}$ 内藤昌『江戸と江戸城』（鹿島出版会、1966）は江戸初期、西和夫『江戸建 築と本途帳』(鹿島出版会、1974）は江戸末期に力点を固いている。『日本名 城集成江戸城了（小学館、1986) は万治度本丸造営と天保度西丸・弘化度本丸・ 万延度本丸造営等を論している。『城郭・侍屋敨古図集成江戸城 I (城郭)』

(至文堂、1992) も大勢は変わりがない。

${ }^{3}$ もちろん最終的には通史的な見解が問われることは十分承知しているが、 現段階では史料的に困難と言わざるを得ない儿、逆に安值に通史を要求する 論者の立場には一定の疑義を示していく必要もあると考えている。

${ }^{4}$ 最近では北原系子『江戸城外堀物語』(筑摩書房、1999) が詳しいが専ら江 戸初期を論じている。

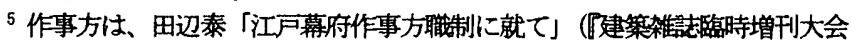
論文集了、1935)、大河值躬「幕府の建築と作事方」(『世界建筑全集』3、平凡 社、1959)、西和夫『江戸建築と本途棏』(鹿島出版会、1974）加詳しい。

6 小普請方は、鈴木解雄「江户幕府小普請方について〕(『日本建筑学会論文 報告集』60、1958）、内藤昌・中村利則「江户幕府小普請方の成立過程につい

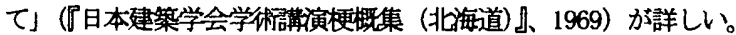

7 批稿「江戸幕府普請方の雇棟梁の雇入とその意義に関する一考察」『日本 建学会計画系論文集』543、2001.5)

${ }^{8}$ 拙稿「江户幕府小谱請方・普請方への棟梁の異動に関する一考察」(『日本 建築学会計画系論文集 $546 、 2001.8$ )

${ }^{9} 1-2$ 鈴木棠三・保田晴男編『近世庶民生活史料末刊日記集成・第五巻玲木修 理日記二』(三一書房、1998) 作事方大工頭鈴木長常長頼父子5の日唔。作事. 普請奉行らと思われるものを含む。文中で適宜述へる。

$101-3$ 8日記四』

I1 $1-3$ 『日記四》

12 1-3『日記四』

${ }^{13}$ 清水門 - 外桜田門も「清水御門建直三之義、対馬守殿江相伺候処二、弥建

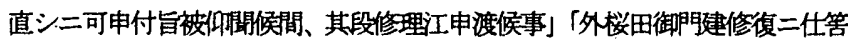
二候へども、殊外損沙二付、建直シ二能成候書付、対馬守殿巧差出候処二、

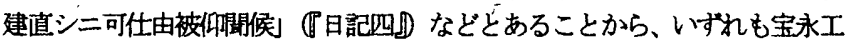
事で解体・再建された可能性があるし、宝氷工事に限った問邀でない点も注 意を要する。

${ }^{14} 1-3$ 『日記四』

15 いずれも富士見御宝蔵番之頭である。(『大日本近世史料・柳営補任』)

${ }^{16} 1$ 『日記二』2-3『日記四』

${ }^{17} 6$ 月 8 日条に記している。

${ }^{18}$ 批稿「江戸の棟梁・職人に関する一考察—巨大都市江戸の建設業者に関す る基磷研究 1 」(『日本建築学会関東支部研究報告集（2000 年度)』、2001. 3)

19 1-3『日記四』

$201-3$ 『日記四』

後注

本稿は科学研究费補助金の成果の一部である。記して感䃑申上げる。 